\title{
Amphibia, Anura, Eleutherodactylidae, Diasporus anthrax (Lynch, 2001): New records and geographic distribution
}

\author{
Felipe Duarte-Cubides* and Nayibe Cala-Rosas \\ 1 Universidad de Antioquia, Facultad de Ciencias Exactas y Naturales, Instituto de Biología, Grupo Herpetológico de Antioquia, Calle 67 \# 53-108, \\ Bloque 7-121, A.A. 1226. Medellín, Colombia. \\ * Corresponding author. E-mail: albetofelipe@gmail.com
}

ABSTRACT: During fieldwork in the Departamentos of Antioquia and Santander we found several specimens of Diasporus anthrax. The new records extend northward its known geographic distribution. We report, for the first time, the presence of D. anthrax on the Cordillera Oriental and discuss some taxonomic implications of these new findings.

Diasporus anthrax Lynch, 2001, is a small frog endemic to Colombia (Figure 1), inhabiting the tropical humid forests of the northern Cordillera Central, at the Magdalena's river valley from 280 and 1200 m elevation (Lynch 2001; Savage 2002; Acosta-Galvis et al. 2006). It is characterized by the presence of an oval palmar tubercle and reddish coloration on the thighs and over the back of the humerus (Lynch 2001). The species has been reported from the Departamento de Caldas (municipios La Dorada and Norcasia), and from the Departamento de Antioquia (municipios de San Luis and San Rafael) (Lynch 2001; Acosta-Galvis et al. 2006; Figure 1).

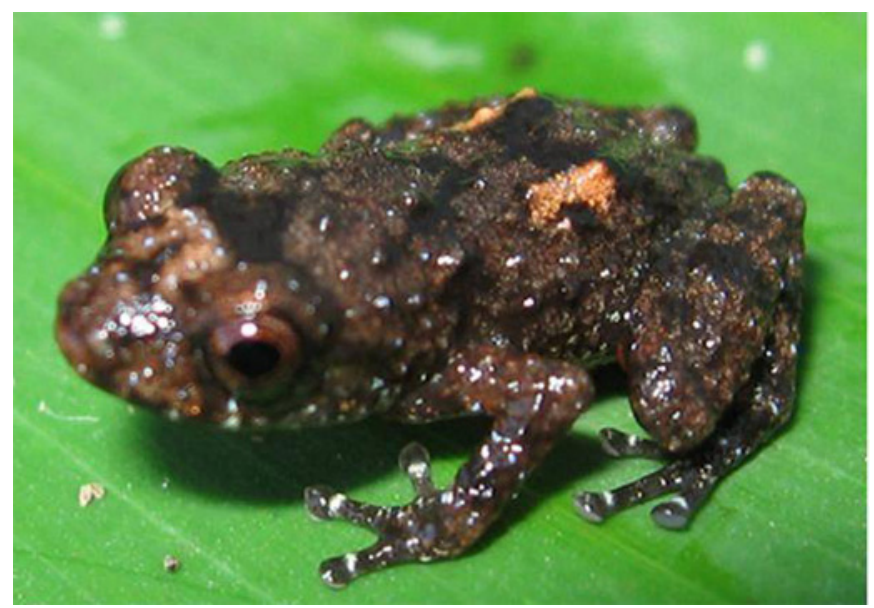

FIGURE 1. Diasporus anthrax collected in Natural Refuge Rio Claro, Municipio de San Luis, Departamento de Antioquia, Colombia. MHUA-A 5877

As a result of recent field trip to the Cordillera Central, Oriental and revision of the herpetological collections at the Universidad de Antioquia, Medellín, and the Instituto de Ciencias Naturales at the Universidad Nacional de Colombia in Bogotá, we add two new localities to the previously known distribution of Diasporus anthrax. The first record $(n=1)$ comes from Finca Santa Bárbara, vereda
Las Brisas, municipio de Maceo (06 $32^{\prime} 49^{\prime \prime} \mathrm{N}, 7^{\circ} 38^{\prime} 37^{\prime \prime}$ W, 499 m elevation). It is located in the Departamento de Antioquia at ca $52.1 \mathrm{~km}$ from the type locality. The specimen was collected after a drizzle on a tree branch and is deposited at the Museo de Herpetología Universidad de Antioquia (MHUA-A 4824). The second record ( $n=2)$ comes from the Natual Reserve Refugio Natural Rio Claro located on the border of the municipios Puerto Triunfo, San Luis and Sonsón, Departamento de Antioquia (0549'60" N, 74²' $21^{\prime \prime}, 350$ m elevation) (MHUA-A 6612-13). One of the specimens was found inside a trash can and the other was collected on leaf-litter in a trail.

The third record $(n=1)$ which extends significantly the known distribution for the species comes from a different locality, specifically in the Departamento de Santander at $195.6 \mathrm{~km}$ at NE from the nearest record. The specimen was collected in the Vereda La Colorada, Municipio San Vicente de Chucurí (0652'36.00" N, 73²3'7.00” W, 1054 m elevation) (MHUA-A 6601), located on the northwestern flank of the Cordillera Oriental, in the Serranía de los Yariguíes. This remarkable specimen was collected during the morning inside of a petiole of the species Xanthosoma sagittifolium (Araceae) growing over a partially flooded soil and surrounded by cacao plantations (Theobroma cacao).

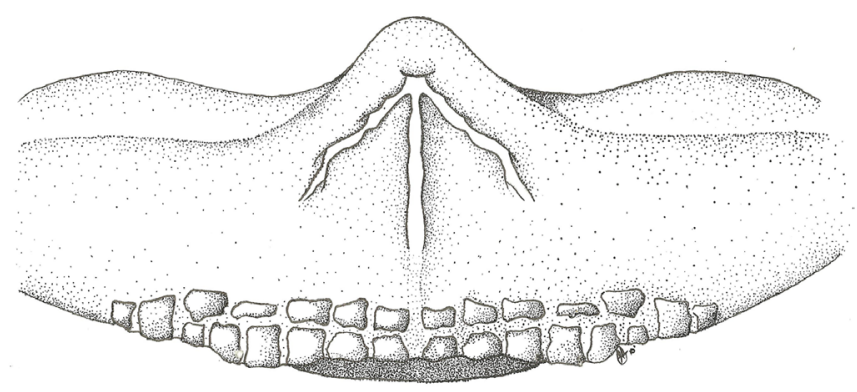

FIGURE 2. Anal denticles showed in all specimens of Diasporus anthrax (rear view), drawn with an increase 32x. 


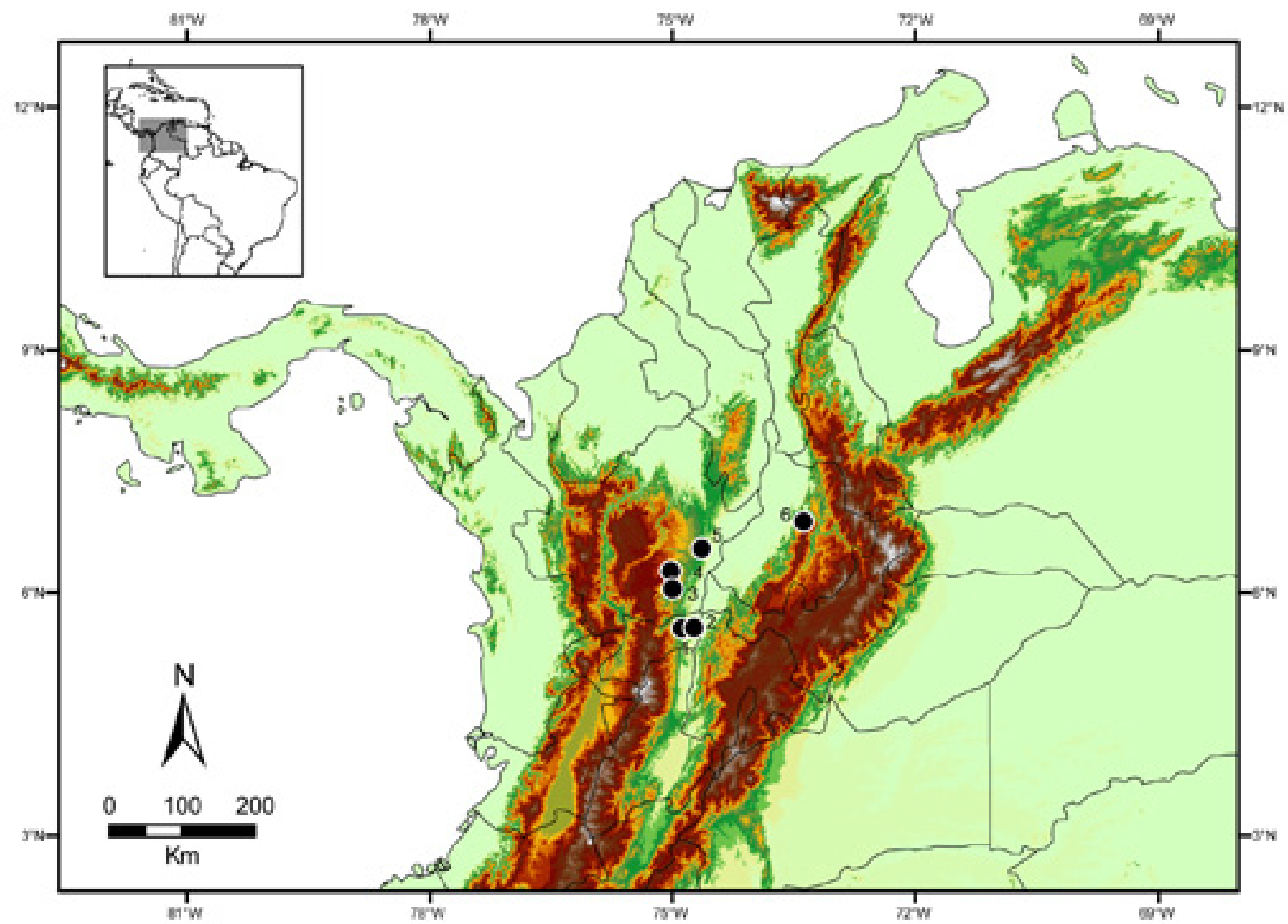

FIGURE 3. Distribution map showing the type locality and new records for Diasporus anthrax. 1. Municipio de Norcasia (Departamento de Caldas), 2. Municipio la Dorada (Departamento of Caldas), 3. Municipio de San Luis (Departamento de Antioquia), 4. Municipio de San Rafael (Departamento de Antioquia), 5. Municipio de Maceo (Departamento de Antioquia), and 6. Municipio de San Vicente de Chucurí (Departamento de Santander).

Examining the external morphology, we found that all individuals from San Luis locality exhibit a triangular shape at the tip of finger III-IV (dorsal view of disk) (spadate disk sensu Savage 1997) and a small ornamentation in ventral view in the finger III. This finding is remarkable because this polimorfic characteristic was not described previously in the original publication, perhaps because the specimens examined did not come from this locality (see Lynch 2001). Additionally, in all examined individuals the anal vent has two posteroventral structures similar to anal denticles described for Caecilians.

Currently, little is known about the natural history and ecology of $D$. anthrax. From the previous studies and our morphological measurements we conclude that body size ranges from 13.7 to $18.7 \mathrm{~mm}$. Habitat data suggest that the species can be found near to water bodies and human settlements. The collected hour the species here report was between 10:00 and 11:00 $\mathrm{h}$ during the day and at the night between 19:00 and 22:00 $\mathrm{h}$.
ACKNowledgments: To Mario Cala Gamarra for give us access to his property in San Vicente de Chucurí. Juan M. Daza and Mauricio Rivera improved the manuscript and Diego Rivera-Prieto and Esteban Alzate collected some specimens. Juan Pablo Hurtado allowed us the photo. John D. Lynch corroborated the specimen from Santander. We also thank the Grupo Herpetologico de Antioquia and the Museo de Herpetologia Universidad de Antioquia (MHUA) and the Instituto de Ciencias Naturales for allow us review the herpetological collections under their care.

\section{LITERATURE CiTED}

Acosta-Galvis, A.R., C. Huertas-Salgado and M. Rada. 2006. Aproximación al conocimiento de los anfibios en una localidad del Magdalena medio (Departamento de Caldas, Colombia). Revista de la Academia Colombiana de Ciencias Exactas, Físicas y Naturales 30(115): 291303.

Lynch, J.D. 2001. Three new rainfrog of the Eleutherodactylus diastema group from Colombia and Panama. Revista de la Academia Colombiana de Ciencias Exactas, Fisicas y Naturales 25(65): 287-297.

Savage, J.M. 1997. A new species of rainfrog of the Eleutherodactylus diastema group from the Alta Talamanca region of Costa Rica. Amphibia-Reptilia 18: 241-247.

Savage, J.M. 2002. The Amphibian and Reptiles of Costa Rica. Chicago: The University Chicago press. $455 \mathrm{p}$.

RECEIVED: February 2011

ACCEPTED: February 2012

PUBLISHED ONLINE: May 2012

EDITORIAL RESPONSIBILITY: Juliana Zina 